\title{
APPLICATION OF DELPHI METHOD IN CONSTRUCTION ENGINEERING AND MANAGEMENT RESEARCH: A QUANTITATIVE PERSPECTIVE
}

\author{
Effah Ernest AMEYAW , Yi HU ${ }^{b}$, Ming SHAN ${ }^{b}$, Albert P. C. CHAN ${ }^{\mathrm{a}}$, Yun $\mathrm{LE}^{\mathrm{b}}$ \\ a Department of Building and Real Estate, The Hong Kong Polytechnic University, \\ Hung Hom, Kowloon, Hong Kong, China \\ ${ }^{b}$ Department of Construction Management and Real Estate, School of Economics and Management, \\ Tongji University, Shanghai, China
}

Received 28 Dec 2013; accepted 22 May 2014

\begin{abstract}
The Delphi method has been used as a main research method by a growing number of researchers in the Construction Engineering and Management (CEM) field in the past two decades. Although a number of studies are available on the use of Delphi, few researchers fully examine the potential of the Delphi method in the combined use of statistical techniques, which is an inevitable trend for future Delphi research. This paper aims to review the combined use of Delphi and other quantitative methods in the CEM field based on a structured literature review of 88 relevant papers. All of the 88 papers are systematically identified from ten well-known peer-reviewed CEM journals published in the period of 1990-2012. Topic coverage, application requirements, and statistical techniques in the 88 Delphi papers are reviewed. The mix use of the Delphi method with three advanced modelling methods, such as Fuzzy sets, Analytical Hierarchy Process, and Analytical Network Process is also examined. These review results provide practical references for researchers having interests in applying Delphi method in CEM research.
\end{abstract}

Keywords: Delphi method, construction engineering and management research, quantitative perspective, review.

\section{Introduction}

The Delphi method is a structured communication and consensus building approach amongst a group of experts on a complex problem (Chan et al. 2001). This method refers to an iterative process where consensus is often reached through rounds of feedbacks of experts' opinion and judgment on a particular subject (Hallowell, Gambatese 2010b). Although sometimes the reliability of the findings derived from a Delphi study may raise some controversy because of the inappropriate design and execution of the Delphi study, such as shortcomings of the survey instrument, poor choice of experts, weak bias control, unreliable analyses, and limited feedback during the study (Gupta, Clarke 1996; Keeney et al. 2001), the Delphi method remains a particularly useful alternative for the situation when objective data are unattainable, there is a lack of empirical evidence, or experimental research is unrealistic or unethical (Hallowell, Gambatese 2010b).

As an established profession in the construction industry, CEM is a practice-driven field in nature. Many research questions in this field need to address the impacts of individuals, organizations and the society on construction management activities, particularly those on planning, forecasting and decision making activities (Fellows, Liu 2009). The key to resolve these problems should draw upon the collective knowledge and experience of selected experts in a given area. By contrast to other methods such as interviews, Delphi provides a more reliable and efficient alternative for solving these problems with high uncertainty (Chan et al. 2001). Therefore, a growing number of researchers have adopted Delphi method in CEM research since the early 1990s (Hallowell, Gambatese 2010b).

Although many researchers regard Delphi as a qualitative method (Hasson et al. 2000), a trend that conduct Delphi in a more quantitative manner by combining quantitative methods has been emerged in the past two decades. In a recent review paper by Hallowell and Gambatese (2010b), they also affirmed this trend. However, limited systematic summary is available on these quantitative Delphi studies. Compared with traditional Delhi studies, quantitative Delphi studies require careful research design and consequently a number of statistical data analysis approaches. Therefore, this study aims to begin to fill this gap by conducting a systematic review of relevant Delphi papers in CEM research. Specific objec-

Corresponding author: Ming Shan

E-mail:ming.shan@connect.polyu.hk 
tives of this study are to: (1) categorize the research topics in which Delphi has been applied, (2) summarize the key requirements of Delphi method, (3) investigate the statistical analysis techniques used for Delphi data, and (4) examine the combined use of Delphi and advanced modeling techniques.

\section{Overview of the Delphi method}

The Delphi concept originated from the American defence industry. The classical Delphi procedures usually comprise at least three rounds of survey (Keeney et al. 2011). Round 1 is to solicit opinions on a certain issue in an open-ended way from the expert panel. Round 2 is to ask panelists to rate the statements in a questionnaire according to their opinions on the subject. Round 3 is to ask panelists to reassess the ratings in the light of the consolidated results from Round 2. Rounds of the survey may continue until a consensus among panelists can fulfil the requirement on some or all of the items. Sometimes Round 1 survey can be skipped when the Round 2 survey questionnaire can be developed through literature review and interviews (Ke et al. 2011; Hon et al. 2012).

\section{Research methodology}

This study conducted a comprehensive review of papers that employed Delphi as the primary or secondary research method and were published in the first-tier CEM journals between 1990 and 2012. The review scope included relevant papers published in the ten selected journals: (1) Construction Management and Economics (CME), (2) Journal of Construction Engineering and Management (JConstr.EM), (3) Engineering, Construction and Architectural Management (ECAM), (4) Journal of Management in Engineering (JME), (5) International Journal of Project Management (IJPM), (6) Automation in Construction (AC), (7) Building Research and Information (BRI), (8) Building and Environment (BE), (9) Journal of Civil Engineering and Management (JCiv. EM), and (10) Journal of Facilities Management (JFM). The first seven journals are among the top journals in the ranking of Chau (1997). The remaining three journals are also widely regarded as the most important sources to obtain high-quality CEM papers (Chan et al. 2009). The common keyword "Delphi" was searched in the ten journals through search engines of Taylor and Francis, ASCE Library, Emerald, and Web of Science (WoS). The total number of relevant papers identified by the initial search was 282. However, not all the initial identified papers used Delphi method as its primary or secondary research method. Some just happened to have the word "Delphi" in their contexts and references. Thus, the initial collection was trimmed via a further visual examination. Only those studies that have clearly specified necessary details of undertaking the Delphi study and satisfied the Delphi requirements are regarded as valid. After the visual examination, 88 papers were finally identified as valid, including CME (16), JConstr.EM (30), ECAM (9),
JME (6), IJPM (16), AC (3), BRI (2), BE (4), JCiv.EM (2), and JFM (2). Figure 1 shows the distribution of the identified Delphi papers in the study period, which has indicated the increasing application trend of the Delphi method in the past two decades. The literature search work was conducted between March and April in 2013.

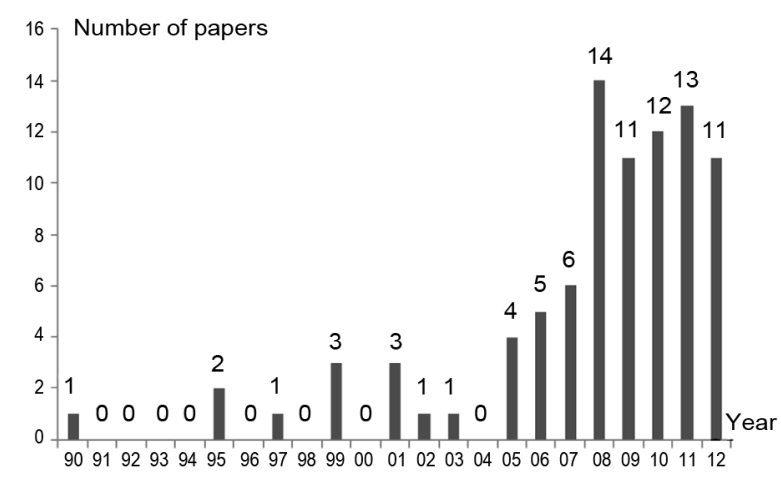

Fig. 1. Identified Delphi papers published between 1990 and 2012

\section{Topic coverage of the Delphi papers}

Considering the good reputation and widespread acceptance of the Journal of Construction Engineering and Management (JConstr.EM) (Chau 1997), its categorization framework of topic coverage was adopted to categorize the topics of the identified Delphi papers (ASCE 2013). Despite the simplicity of this categorization framework, the framework remains familiar and easily understandable to CEM researchers. Within the 88 identified papers, in addition to the three review papers of Chan et al. (2009), Hallowell and Gambatese (2010b), and Lucko and Rojas (2010), research topics of the remaining 85 Delphi papers could be grouped under seven categories as shown in Figure 2.

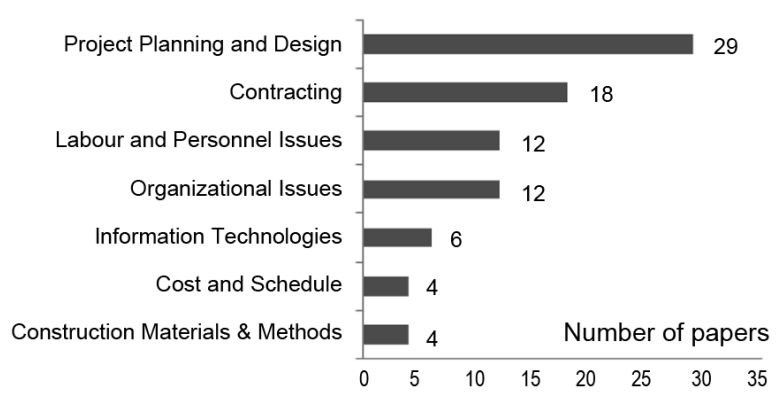

Fig. 2. Distribution of research interests in the identified Delphi papers

Project planning and design ranked first with 29 papers involved. Majority of these papers employed Delphi as a forecasting instrument to identify and evaluate certain risks for managing a specific type of projects, such as financial risks (Thomas et al. 2006; Lyer, Sagheer 2010; $\mathrm{Xu}$ et al. 2010a, 2010b; Ke et al. 2010, 2011), technical risks (Seo, Choi 2008), execution risks (Aritua et al. 
2011; del Caño, de la Cruz 2002; de la Cruz et al. 2006), as well as contractual and cost risks (Tummala, Burchett 1999; Adams 2006, 2008). Aside from these studies on risk management, the Delphi method could be also used to investigate factors regarding engineering design and pre-project planning. For instance, Pan (2008) applied the Delphi method to explore the factors affecting the decision making on the selection of bridge construction methods. Wu et al. (2007) used this method to identify the evaluation criteria for selecting on the optimal project location.

The contracting issue received the second ranking with 18 papers involved. Some researchers identified the selection criteria for project procurement methods by using the Delphi method (Chan et al. 2001; Lee, Kim 2001). Delphi was also commonly employed to resolve procurement-related evaluations in different types of projects, such as Design-Build projects and Public-Private Partnership projects (Brown et al. 2001; Yeung et al. 2007, 2008, 2009a, 2009b, 2012; Kumaraswamy, Anvuur 2008; Xia et al. 2009, 2011; Xia, Chan 2010, 2012b).

Labour and personnel issues ranked third with 12 papers involved. Most of these studies focused on safety management. Many researchers utilized Delphi to evaluate the effectiveness of safety programs or systems (Hallowell, Gambatese 2009a, 2010a; Rajendran, Gambatese 2009; Hallowell, Calhoun 2011; Hallowell et al. 2011; Hon et al. 2012; Shapira, Lyachin 2009). Delphi was also used to identify and evaluate personal issues, such as irregular behaviour (Tabish, Jha 2011), professional attributes (Hackett, Hicks 2007), and engineer competences (Yik et al. 2012).

Organizational issues also received the third ranking with 12 papers involved. These studies mainly used Delphi to develop certain solutions for construction organizations, such as internationalization, corporate financing, corporate competences, and business (Gunhan, Arditi 2005a, 2005b; Chen, Hsu 2008; Hsu et al. 2008; Dikmen et al. 2010; Lu 2010; Cha, O'Connor 2005). Additionally, Delphi was used to explore a reasonable organization design and the influence of organization culture (Gajendran, Brewer 2007; Elbarkouky, Fayek 2011; Lin 2011).

The number of papers on information technologies ranked fifth. Six papers were devoted to this area. These studies mainly employed Delphi to evaluate the effectiveness and outcomes of innovative technologies and systems (Karlsson et al. 2008; Cooke et al. 2008; Dawood, Sikka 2009; Dawood 2010; Lin et al. 2011).

Four papers on cost and schedule were identified (Chau 1995; Shaheen et al. 2007; Pivo 2008; Chan 2012). These studies mainly used Delphi as forecasting and evaluation tools.

Construction Materials and Methods also have four papers involved. Among these studies, Delphi was mainly used to evaluate the effectiveness of various construction methods and technologies (Arditi, Gunaydin 1999; Sarkar, Dutta 2010; Hallowell, Gambatese 2009b; Yasamis-Speroni et al. 2012).

\section{Key requirements for the Delphi method}

\subsection{Selection of Delphi panelists}

The success of Delphi studies mainly depends on the careful and objective selection of expert panelists (Chan et al. 2001). Those experts involved in a Delphi study refers to professionals or researchers having special knowledge/ experience, which are evident by several specific requirements such as working appointments, professional qualifications, working experience, and relevant publications (Hallowell 2008). The majority of the identified Delphi papers (64 out of 88) indicated the requirements for the selection of experts. Two sets of the qualification of expert panelists were adopted: (1) specific requirements, and (2) a flexible point system. Some researchers adopted clear criteria to qualify experts. For example, Chan et al. (2001) and Manoliadis et al. (2006) adopted the working experience and the involvement in a certain kind of projects as key criteria to qualify experts. Meanwhile, Hallowell and Gambatese (2010b) and Hallowell et al. (2011) recommended that an identified expert scores a minimum of 12 total points in an expert evaluation system to qualify for participation in a study.

\subsection{Number of expert panelists}

Extant CEM literature is inconclusive on the optimal size of a Delphi panel. Some researchers believe that the bigger panel size can yield more reliable results (Murphy et al. 1998). Others have argued that there is no significant correlation between the size of a Delphi panel and accuracy and effectiveness of the Delphi method (Boje, Murnighan 1982). However, the variation in numbers of Delphi panelists results from several factors, including: the scope or nature of the problem under investigation, number of available experts, and available resources in terms of time and money (Hallowell, Calhoun 2011; Manoliadis et al. 2006; Chan et al. 2001; Hasson et al. 2000). In all 88 identified papers, 67 papers specified the sizes of the expert panel employed. The size of the expert panel involved in these studies ranged from 3 to 93 . Table 1 has indicated that majority of researchers are inclined to employ a panel size between 8 and 20 in their CEM researches.

\subsection{Number of rounds}

The number of rounds is an essential aspect in design a Delphi study, which aims at reaching consensus among panelists through controlled and anonymous feedback and iterative process (Hallowell, Gambatese 2010b).

Table 1. Panel sizes in identified Delphi papers

\begin{tabular}{|c|c|c|c|c|c|c|c|}
\hline Panel size & in & $\stackrel{\overbrace{}}{\grave{1}}$ & $\frac{i}{i}$ & $\frac{8}{9}$ & $\frac{\stackrel{P}{i}}{\frac{1}{\gamma}}$ & $\begin{array}{l}0 \\
0 \\
0 \\
\tilde{\sigma} \\
\overline{0} \\
\bar{n}\end{array}$ & Total \\
\hline Frequency & 7 & 41 & 9 & 5 & 4 & 1 & 67 \\
\hline
\end{tabular}


However, there is no specific guidance on the optimal number of rounds in Delphi studies in previous literature and therefore researchers tend to settle on different number of rounds given their desired level of consensus. Among the identified 88 papers, the number of rounds ranges from two to six. It is worth noting that the 40 of the identified 88 papers have reached desired consensus after two and three rounds. This is in line with the observation of Dalkey et al. (1970) that Delphi results are more accurate after two iterations. Nevertheless, in the case of more than three iterations involved, the researcher should consider issues of participant fatigue, attrition rates, time, and cost (Hasson et al. 2000). For example, in the three identified papers by Chan et al. (2001), Rajendran and Gambatese (2009), and Xia et al. (2011), the number of experts involved started dropping out of the studies after Round 2.

\subsection{Anonymous feedback process}

Linstone and Turoff (1975) stated that, in Delphi studies, providing anonymous feedback facilitates indirect communication among respondents to reach a high level of consensus. Hallowell and Gambatese (2010b) also emphasized that the process is not a Delphi without the iterative and feedback processes. Based on reviewing the 88 identified papers, the common simple statistical feedback between the rounds is mean or median (32 out of 88 papers).

\section{Statistical analysis tests for the Delphi data}

A growing number of Delphi papers which used advanced statistical techniques in data analysis have been identified in the past two decades as shown in Figure 3. Statistical analysis techniques were adopted in data analysis of Delphi survey mainly for three different purposes: consensus measurement, inter-group comparison and correlation analysis. Table 2 summarizes statistical tests used for each purpose of the identified Delphi papers. Statistical Package for the Social Sciences (SPSS) software is the most frequently used software for conducting statistical analysis on Delphi data.

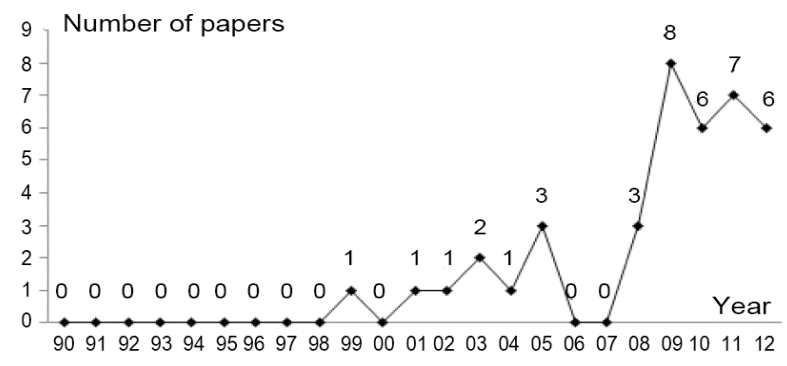

Fig. 3. Number of Delphi papers using statistical analysis techniques between 1990 and 2012
Table 2. Statistical analysis techniques used in identified Delphi studies

\begin{tabular}{l|l|c}
\hline \multicolumn{1}{c|}{ Purpose } & \multicolumn{1}{|c}{ Techniques } & Frequency \\
\hline $\begin{array}{l}\text { Consensus } \\
\text { measurement }\end{array}$ & Deviation & 16 \\
& $\begin{array}{l}\text { Kendall's coefficient of } \\
\text { concordance }(W)\end{array}$ & 15 \\
Chi-square $\left(\chi^{2}\right)$ & 3 \\
$\begin{array}{l}\text { Inter-group } \\
\text { comparison }\end{array}$ & Spearman rank correlation & 4 \\
& test & 1 \\
$\begin{array}{l}\text { Wilcoxon signed rank test } \\
\text { analysis }\end{array}$ & Kruskal-Wallis test & 1 \\
\hline
\end{tabular}

\subsection{Attitude scales}

Nearly half of the identified Delphi papers (41 out of 88 papers) adopted a Likert scale to quantify the opinions of experts on a specific subject. As shown in Table 3, the attitude scales adopted in the identified Delphi papers were in the range between 3 and 12. The five-point Likert scale was used mostly with the frequency of 22 . The increasing use of ten-point Likert scale was also observed. It should be noted that the attitude scale employed in Delphi questionnaires should be in a range of over five points to sustain measurement accuracy because most Delphi sample sizes are small (Hsu, Sandford 2007).

Table 3. Attitude scales in identified Delphi studies

\begin{tabular}{l|c|c|c|c|c|c|c|c|c}
\hline Attitude scale & 3 & 4 & 5 & 6 & 7 & 9 & 10 & 12 & Total \\
\hline Frequency & 4 & 2 & 22 & 1 & 2 & 2 & 7 & 1 & 41 \\
\hline
\end{tabular}

Apart from the Likert scale, a centesimal system was also used in a few Delphi studies to collect panelists' opinions (Chan et al. 2001; del Caño, de la Cruz 2002; Adams 2008). For example, in Chan's et al. (2001) study that investigated criteria for the selection of procurement systems for construction projects, panelists were requested to provide ratings of the utility attribute of each selection criterion against each selected procurement system based on a centesimal system.

\subsection{Consensus measurement}

The use of the Delphi method is to achieve consensus among the Delphi panelists (Chan et al. 2001). Thus consensus measurement is a critical work in data analysis of Delphi survey. However, given the uniqueness of Delphi data across different CEM areas, determination of the level of consensus varies. Hence, it is impossible to suggest an optimal level of consensus for Delphi studies across different CEM areas. Based on the review work of the 88 Delphi papers, three techniques were identified as the major tools in measuring the consensus among the panel experts, namely, Deviation, Kendall's coefficient of concordance $(W)$, and Chi-square $\left(\chi^{2}\right)$.

Table 2 shows that deviation received the most advocacies in measuring the consensus degree of different 
rounds of Delphi survey (16 papers). Absolute deviation and standard deviation of absolute deviation were the most popular indicators employed. A number of researchers favoured the use of absolute deviation to measure the absolute difference to the mean value of a data set and set an absolute variance of less than $5 \%$ or $10 \%$ as an threshold in their studies (Hallowell, Gambatese 2009a, 2009b, 2010a; Hallowell et al. 2011; Hallowell, Calhoun 2011). The use of standard deviation in consensus measurement was also widely adopted in CEM areas such as organization issues, contracting, project planning and design, as well as information technologies (Arditi, Gunaydin 1999; del Caño, de la Cruz 2002; Gunhan, Arditi 2005a, 2005b; Chinowsky et al. 2007; Dawood, Sikka 2009; Dawood 2010; Vidal et al. 2011; Yu, Kwon 2011; Yasamis-Speroni et al. 2012). However, there is no agreement on the minimum value of standard deviation, under which the consensus of the Delphi survey could be accepted. Some researchers accepted the ratio of $30 \%$ that standard deviation value against a mean value of a data set, although this ratio indicates that a certain difference existing among the data (Chinowsky et al. 2007; Vidal et al. 2011; Yasamis-Speroni et al. 2012).

Kendall's coefficient of concordance $(W)$ is another technique commonly used to test the level of concordance (consensus) among the expert panelists (Xia et al. 2009; Hon et al. 2012; Hallowell et al. 2011). In this study, fifteen of the identified Delphi papers employed this technique. The $W$ value indicates the degree of agreement between the panel members by taking into account the variations between the rankings of mean of different variables (Hon et al. 2012). A concordance coefficient of " 1 " means $100 \%$ consensus. It can be construed that the $W$ value should be increased along with a successive Delphi survey rounds. Within the identified Delphi papers, the $W$ value ranged from 0.234 to 0.600 (Hon et al. 2012; Pivo 2008).

Chi-square should be recommended to be adopted when the number of variables to be evaluated is larger than seven (Siegel, Castellan 1988). Views of the Delphi panelists reach a consensus when the computed Chisquare value is larger than the critical Chi-square value (Ke et al. 2010, 2011; Hon et al. 2012).

\subsection{Inter-group comparison}

It is widely accepted that setting the boundary within the expert panel can improve the validity of the Delphi studies. Thus, inter-group analysis should be conducted to test whether there is any substantially similar agreement among the respondents from different subgroups before combining the data from various subgroups (Hon et al. 2012). Since Likert data were usually treated as ordinal data in the identified Delphi papers, three non-parametric statistical techniques, namely, Spearman's rank correlation coefficient, Wilcoxon signed rank test, and KruskalWallis test were found to be used for the inter-group comparison.
Four identified Delphi papers use Spearman's rank correlation coefficient to test the inter-group comparison (Arditi, Gunaydin 1999; Hackett, Hicks 2007; Ke et al. 2010, 2011). If the computed Spearman's rank correlation coefficient exceeds the critical value at a significance level (of say 0.05), it can be construed that there is consistence between the different respondent groups (Ke et al. 2011).

Two identified Delphi papers employed Wilcoxon Signed Rank test to examine the inter-group comparison (Hallowell, Calhoun 2011; Yasamis-Speroni et al. 2012). If the computed test statistics is less than the critical value at a significance level (of say 0.10 ), there is no significant difference among the views of experts those belong to different subgroups (Yasamis-Speroni et al. 2012).

In addition, Hon et al. (2012) conducted a KruskalWallis test on experts' evaluation of difficulties of implementing safety practices in the repair and maintenance sector within three expert subgroups, namely, client subgroup, contractor subgroup, and occupational health and safety consultants/regulatory subgroup. Hon et al. (2012) mentioned that if the computed Kruskal-Wallis test value is less than the critical value at a significance level (of say 0.05), this indicates that consensus among different subgroups are achieved.

\subsection{Correlation analysis}

In some cases, Delphi method is used to examine independent variables regarding a particular construct which are identified from literature reviews, interviews, or a combination of these two methods (Xia et al. 2009). Thus correlation analysis of variables in a Delphi survey should be performed. Pearson Correlation Matrix is a primary form of correlation analysis used in the identified Delphi studies (Yeung et al. 2007, 2008, 2009a, 2009b, 2012; Xia et al. 2009, 2011; Xu et al. 2010a, 2010b; Xia, Chan 2010, 2012a, 2012b).

As indicated earlier in Section 5.3, Likert data collected in the identified Delphi papers were usually treated as ordinal data. A controversy exists in the analysis of ordinal data that, Pearson Correlation Matrix, a parametric statistical technique can better handle interval data rather than ordinal data. However, much documentation has confirmed that parametric statistical technique could also be used for the ordinal data when the different response categories are equal (Kim 1975; Allan 1976; Weisberg et al. 1996; Norman 2010; Hwang et al. 2013, 2014; Zhao et al. 2013). Thus, the use of Pearson Correlation Matrix to check the correlations of different variables in the identified Delphi papers is acceptable. Its high exposure rate in the identified Delphi papers also reveals a great application potential (Yeung et al. 2007, 2008, 2009a, 2009b, 2012; Xu et al. 2010a, 2010b; Xia, Chan 2010, 2012a, 2012b; Xia et al. 2009, 2011). 


\section{Combination of Delphi and other advanced modeling methods}

To yield stronger and more reliable findings, some researchers have attempted to combine Delphi with other advanced modeling methods in their CEM studies. Based on the 88 identified Delphi papers, Fuzzy Sets, Analytical Hierarchy Process (AHP), and Analytical Network Process (ANP) were the most common modeling methods employed in previous Delphi studies. Figure 4 shows the development of the trend of combining Delphi with the three modelling methods in the past two decade.

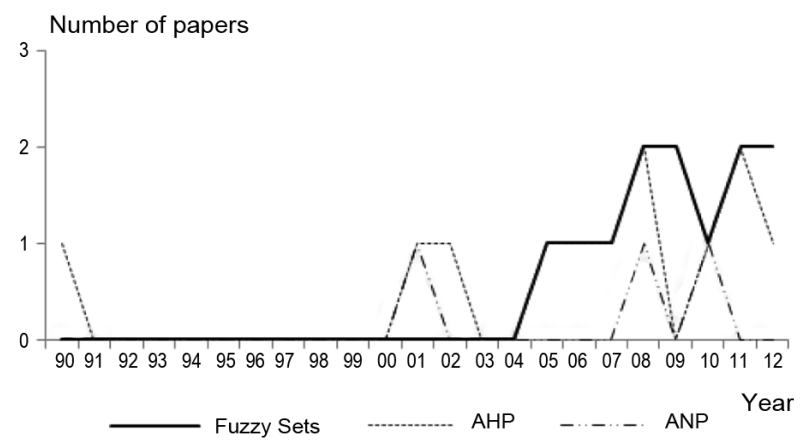

Fig. 4. Number of Delphi papers having combined fuzzy sets, AHP, and ANP

\subsection{Combination with Fuzzy sets}

Many research questions associated with the construction industry are complex, uncertain, and sensitive to the environment (Chan et al. 2009). Under such circumstances, Fuzzy Theory is regarded as a proper option to deal these problems (Nasirzadeh et al. 2008; Manoliadis et al. 2009). Fuzzy Theory is a branch of modern mathematics that has been first formulated by Zadeh (1965), which includes two fundamental concepts, fuzzy sets and fuzzy logic. Compared with fuzzy logic, Fuzzy sets are the more popular methods employed in the CEM field (Chan et al. 2009). Among the 88 papers identified, twelve papers adopted Fuzzy Sets in Delphi studies. These papers could be categorized into two groups: Fuzzy Delphi and Fuzzy Set Analysis.

Fuzzy Delphi is a modified Delphi method in terms of Fuzzy sets developed by Murray et al. (1985). Compared with classic Delphi, this method used a fuzzymembership response system instead of the single-choice response system, which allows experts involved to express the vagueness in answering survey questions. Six papers identified in this study have utilized the Fuzzy Delphi method (Dzeng, Wen 2005; Thomas et al. 2006; Shaheen et al. 2007; Nasirzadeh et al. 2008; Manoliadis et al. 2009; Lin et al. 2011). The other stretch of research attempts to combine Delphi and Fuzzy sets is to analyse Delphi data through Fuzzy set analysis. Under such circumstance, the Delphi method and Fuzzy set analysis are adopted sequentially in the research design. Six identified Delphi papers adopted this combined research approach (Pan 2008; Xu et al. 2010a; Elbarkouky, Fayek
2011; Khazaeni et al. 2012; Xia et al. 2011; Yeung et al. 2012).

Particularly, of the 12 papers combining Delphi and Fuzzy sets, four papers were identified on project risk management (Thomas et al. 2006; Nasirzadeh et al. 2008; $\mathrm{Xu}$ et al. 2010a; Khazaeni et al. 2012), three papers on procurement (Dzeng, Wen 2005; Manoliadis et al. 2009; Xia et al. 2011). This indicates that a mixed use of Delphi and Fuzzy sets are more appropriate for research topics related to the two areas.

\subsection{Combination with AHP}

The AHP method was first developed by Saaty (1980) and assisted in developing a useful multiple criteria decision making tool dealing with economic, technical, and social issues. One major advantage of AHP is that it can convert a particular subject that is intangible and difficult to quantify into quantified and tangible values by using a systematic approach (Hyun et al. 2008). To assist in the decision making on these complicated issues, the AHP considers the trade-offs and evaluates the level of relative importance among various factors related to the issues using pairwise comparison (Khasnabis et al. 2002; Shapira, Goldenberg 2005). Some researchers affirmed this merit of AHP and used this technique to quantify Delphi survey results. In this study, twelve papers that used a combination of Delphi and AHP were identified (Shields et al. 1988; Brown et al. 2001; Khasnabis et al. 2002; Shapira, Goldenberg 2005; Bertolini et al. 2006; Wu et al. 2007; Hsu et al. 2008; Hyun et al. 2008; Lu 2010; Lin 2011; Vidal et al. 2011; Khazaeni et al. 2012). Topics of these identified papers refer to various CEM areas, such as organizational issues, contracting, project planning and design, labour and personnel issues, and information technologies (ASCE 2013). This suggests a wide application of the combined approach of Delphi and AHP method.

\subsection{Combination with ANP}

ANP is a useful method used to deal with a number multiple decision making problems in the construction domain (Chen et al. 2008). It is regarded as a generalized form of the AHP method (Saaty 1996). Since the AHP does not allow interdependencies between the components of a problem, the ANP can be used as an effective tool in those cases (Dikmen et al. 2010). Therefore, the advantage of ANP is that it provides more reliable decision-making support by quantitatively measuring all possible interrelations among indicators based on reuse of the experts' knowledge. In this study, three papers combining ANP with Delphi were identified (Lee, Kim 2001; Chen et al. 2008; Dikmen et al. 2010).

\section{Conclusions}

This comprehensive literature review reveals that Delphi is a robust tool for identifying, evaluating, and forecasting purpose in areas of project planning and design, contracting, labour and personnel issues, and organiza- 
tional issues in CEM research. Application of Delphi in the 88 identified papers shows that researchers are more inclined to adopt this method within an expert panel of 8-20 members specialized selected in two or three rounds of solicitation, by using mean or median as the most common feedback process. An evident increasing trend of using statistical techniques to analyse data collected in Delphi surveys has been detected. Various statistical analysis techniques utilized to measure the consensus, inter-group comparison, and correlation of the data provided by the Delphi panel are scrutinized in details. This review paper also reveals the combined use of the Delphi method with three advanced modeling techniques, namely, Fuzzy sets, Analytical Hierarchy Process, and Analytical Network Process. By combining these advanced techniques, Delphi will have a greater application potential for addressing the ambiguous and imprecise events in CEM area.

\section{Acknowledgements}

This study is funded by the Joint $\mathrm{PhD}$ program between The Hong Kong Polytechnic University and Tongji University, and the National Natural Science Foundation of China (Grant code: 71172107; 71390523). The authors would like to give their thanks to the Department of Building and Real Estate at the Hong Kong Polytechnic University, and the Research Institute of Complex Engineering \& Management at Tongji University for providing support to this study.

\section{References}

Adams, F. K. 2006. Expert elicitation and Bayesian analysis of construction contract risks: an investigation, Construction Management and Economics 24(1): 81-96. http://dx.doi.org/10.1080/01446190500310254

Adams, F. K. 2008. Risk perception and Bayesian analysis of international construction contract risks: the case of payment delays in a developing economy, International Journal of Project Management 26(2): 138-148.

http://dx.doi.org/10.1016/j.ijproman.2007.05.007

Allan, G. J. B. 1976. Ordinal-scaled variables and multivariate analysis: comment on Hawkes, American Journal of Sociology 81(6): 1498-1500. http://dx.doi.org/10.1086/226239

ASCE. 2013. Aims and scope [online], [cited 12 December 2013]. Available from Internet: http://ascelibrary.org/page/ jcemd4/editorialboard? curLocale $=4$

Arditi, D.; Gunaydin, H. M. 1999. Perceptions of process quality in building projects, Journal of Management in Engineering 15(2): 43-53. http://dx.doi.org/10.1061/(ASCE)0742-597X(1999)15:2(43)

Aritua, B.; Smith, N. J.; Bower, D. 2011. What risks are common to or amplified in programmes: evidence from UK public sector infrastructure schemes, International Journal of Project Management 29(3): 303-312. http://dx.doi.org/10.1016/j.ijproman.2010.04.004

Bertolini, M.; Braglia, M.; Carmignani, G. 2006. Application of the AHP methodology in making a proposal for a public work contract, International Journal of Project Management 24(5): 422-430. http://dx.doi.org/10.1016/j.ijproman.2006.01.005

Boje, D. M.; Murnighan, J. K. 1982. Group confidence pressures decisions, Management Science 28(1): 1187-1196. http://dx.doi.org/10.1287/mnsc.28.10.1187
Brown, D. C.; Ashleigh, M. J.; Riley, M. J.; Shaw, R. D. 2001. New project procurement process, Journal of Management in Engineering 17(4): 192-201.

http://dx.doi.org/10.1061/(ASCE)0742-597X(2001)17:4(192)

Cha, H. S.; O'Connor, J. T. 2005. Optimizing implementation of value management processes for capital projects, Journal of Construction Engineering and Management 131(2): 239-251.

http://dx.doi.org/10.1061/(ASCE)0733-9364(2005)131:2(239)

Chan, A. P. C.; Chan, D. W. M.; Yeung, J. F. Y. 2009. Overview of the application of "fuzzy techniques" in construction management research, Journal of Construction Engineering and Management 135(11): 1241-1252. http://dx.doi.org/10.1061/(ASCE)CO.1943-7862.0000099

Chan, A. P. C.; Yung, E. H. K.; Lam, P. T. I.; Tam, C. M.; Cheung, S. O. 2001. Application of Delphi method in selection of procurement systems for construction projects, Construction Management and Economics 19(7): 699718. http://dx.doi.org/10.1080/01446190110066128

Chan, C. T. W. 2012. The principal factors affecting construction project overhead expenses: an exploratory factor analysis approach, Construction Management and Economics 30(10): 903-914.

http://dx.doi.org/10.1080/01446193.2012.717706

Chau, K. W. 1995. The validity of the triangular distribution assumption in Monte Carlo simulation of construction costs: empirical evidence from Hong Kong, Construction Management and Economics 13(1): 15-21.

http://dx.doi.org/10.1080/01446199500000003

Chau, K. W. 1997. The ranking of construction management journals, Construction Management and Economics 15(4): 387-398. http://dx.doi.org/10.1080/014461997372953

Chen, J. H.; Hsu, S. C. 2008. Quantifying impact factors of corporate financing: engineering consulting firms, Journal of Management in Engineering 24(2): 96-104.

http://dx.doi.org/10.1061/(ASCE)0742-597X(2008)24:2(96)

Chen, Z.; Li, H.; Ross, A.; Khalfan, M. M. A.; Kong, S. C. W. 2008. Knowledge-driven ANP approach to vendors evaluation for sustainable construction, Journal of Construction Engineering and Management 134(12): 928-941.

http://dx.doi.org/10.1061/(ASCE)0733-9364(2008)134:12(928)

Chinowsky, P. S.; Molenaar, K.; Bastias, A. 2007. Measuring achievement of learning organizations in construction, Engineering, Construction and Architecture Management 14(3): 215-227.

http://dx.doi.org/10.1108/09699980710744872

Cooke, T.; Lingard, H.; Blismas, N.; Stranieri, A. 2008. ToolSHeDTM: the development and evaluation of a decision support tool for health and safety in construction design, Engineering, Construction and Architecture Management 15(4): 336-351. http://dx.doi.org/10.1108/09699980810886847

Dalkey, N.; Brown, B.; Cochran, S. 1970. Use of self-ratings to improve group estimates, Technological Forecasting 1(3): 283-291. http://dx.doi.org/10.1016/0099-3964(70)90029-3

Dawood, N. 2010. Development of 4D-based performance indicators in construction industry, Engineering, Construction and Architecture Management 17(2): 210-230. http://dx.doi.org/10.1108/09699981011024704

Dawood, N.; Sikka, S. 2009. Development of 4D based performance indicators in construction industry, Engineering, Construction and Architecture Management 16(5): 438458. http://dx.doi.org/10.1108/09699980910988357

de la Cruz, M. P.; del Caño, A.; de la Cruz, E. 2006. Downside risks in construction projects developed by the civil service: the case of Spain, Journal of Construction Engineering and Management 132(8): 844-852.

http://dx.doi.org/10.1061/(ASCE)0733-9364(2006)132:8(844) 
del Caño, A.; de la Cruz, M. P. 2002. Integrated methodology for project risk management, Journal of Construction Engineering and Management 128(6): 473-485.

http://dx.doi.org/10.1061/(ASCE)0733-9364(2002)128:6(473)

Dikmen, I.; Birgonul, M. T.; Ozorhon, B.; Sapci, N. E. 2010. Using analytic network process to assess business failure risks of construction firms, Engineering, Construction and Architecture Management 17(4): 369-386. http://dx.doi.org/10.1108/09699981011056574

Dzeng, R. J.; Wen, K. S. 2005. Evaluating project teaming strategies for construction of Taipei 101 using resourcebased theory, International Journal of Project Management 23(6): 483-491.

http://dx.doi.org/10.1016/j.ijproman.2005.02.004

Elbarkouky, M. M. G.; Fayek, A. R. 2011. Fuzzy similarity consensus model for early alignment of construction project teams on the extent of their roles and responsibilities, Journal of Construction Engineering and Management 137(6): 432-440. http://dx.doi.org/10.1061/(ASCE)CO.1943-7862.0000310

Fellows, R. F.; Liu, A. M. 2009. Research methods for construction. $3^{\text {rd }}$ ed. Chichester, West Sussex, UK: John Wiley and Sons Ltd. 320 p.

Gajendran, T.; Brewer, G. 2007. Integration of information and communication technology: influence of the cultural environment, Engineering, Construction and Architecture Management 14(6): 532-549. http://dx.doi.org/10.1108/09699980710829003

Gunhan, S.; Arditi, D. 2005a. International expansion decision for construction companies, Journal of Construction Engineering and Management 131(8): 928-937.

http://dx.doi.org/10.1061/(ASCE)0733-9364(2005)131:8(928)

Gunhan, S.; Arditi, D. 2005b. Factors affecting international construction, Journal of Construction Engineering and Management 131(3): 273-282.

http://dx.doi.org/10.1061/(ASCE)0733-9364(2005)131:3(273)

Gupta, U. G.; Clarke, R. E. 1996. Theory and applications of the Delphi technique: a bibliography (1975-1994), Technological Forecasting and Social Change 53(2): 185-211. http://dx.doi.org/10.1016/S0040-1625(96)00094-7

Hackett, J. A.; Hicks, C. M. 2007. Estimating as a profession in UK construction, Engineering, Construction and Architecture Management 14(1): 26-51. http://dx.doi.org/10.1108/09699980710716963

Hallowell, M. 2008. A formal model of construction safety and health risk management: $\mathrm{PhD}$ dissertation. Oregon State University, Corvallis, Oregano, USA.

Hallowell, M. R.; Calhoun, M. E. 2011. Interrelationships among highly effective construction injury prevention strategies, Journal of Construction Engineering and Management 137(11): 985-993.

http://dx.doi.org/10.1061/(ASCE)CO.1943-7862.0000354

Hallowell, M. R.; Gambatese, J. A. 2009a. Construction safety risk mitigation, Journal of Construction Engineering and Management 135(12): 1316-1323.

http://dx.doi.org/10.1061/(ASCE)CO.1943-7862.0000107

Hallowell, M. R.; Gambatese, J. A. 2009b. Activity-based safety risk quantification for concrete formwork construction, Journal of Construction Engineering and Management 135(10): 990-998. http://dx.doi.org/10.1061/(ASCE)CO.1943-7862.0000071

Hallowell, M. R.; Gambatese, J. A. 2010a. Population and initial validation of a formal model for construction safety risk management, Journal of Construction Engineering and Management 136(9): 981-990. http://dx.doi.org/10.1061/(ASCE)CO.1943-7862.0000204

Hallowell, M. R.; Gambatese, J. A. 2010b. Qualitative research: application of the Delphi method to CEM research,
Journal of Construction Engineering and Management 136(1): 99-107.

http://dx.doi.org/10.1061/(ASCE)CO.1943-7862.0000137

Hallowell, M. R.; Esmaeili, B.; Chinowsky, P. 2011. Safety risk interactions among highway construction work tasks, Construction Management and Economics 29(4): 417-429. http://dx.doi.org/10.1080/01446193.2011.552512

Hasson, F.; Keeney, S.; McKenna, H. 2000. Research guidelines for the Delphi survey technique, Journal of Advanced Nursing 32(4): 1008-1015.

Hon, C. K. H.; Chan, A. P. C.; Yam, M. C. H. 2012. Empirical study to investigate the difficulties of implementing safety practices in the repair and maintenance sector in Hong Kong, Journal of Construction Engineering and Management 138(7): 877-884.

http://dx.doi.org/10.1061/(ASCE)CO.1943-7862.0000497

Hsu, C. C.; Sandford, B. A. 2007. The Delphi technique: making sense of consensus, Practical Assessment, Research \& Evaluation 12(10): 1-8.

Hsu, P. F.; Wu, C. R.; Li, Z. R. 2008. Optimizing resource-based allocation for senior citizen housing to ensure a competitive advantage using the analytic hierarchy process, Building and Environment 43(1): 90-97.

http://dx.doi.org/10.1016/j.buildenv.2006.11.028

Hwang, B.-G.; Zhao, X.; Goh, K. J. 2013. Investigating the client-related rework in building projects: the case of Singapore, International Journal of Project Management 32(4): 698-708.

http://dx.doi.org/10.1016/j.ijproman.2013.08.009

Hwang, B. G.; Zhao, X.; Toh, L. P. 2014. Risk management in small construction projects in Singapore: status, barriers and impact, International Journal of Project Management 32(1): 116-124.

http://dx.doi.org/10.1016/j.ijproman.2013.01.007

Hyun, C. T.; Cho, K.; Koo, K. J.; Hong, T. H.; Moon, H. S. 2008. Effect of delivery methods on design performance in multifamily housing projects, Journal of Construction Engineering and Management 134(7): 468-482.

http://dx.doi.org/10.1061/(ASCE)0733-9364(2008)134:7(468)

Karlsson, M.; Lakka, A.; Sulankivi, K.; Hanna, A. S.; Thompson, B. P. 2008. Best practices for integrating the concurrent engineering environment into multipartner project management, Journal of Construction Engineering and Management 134(4): 289-299.

http://dx.doi.org/10.1061/(ASCE)0733-9364(2008)134:4(289)

Ke, Y.; Wang, S. Q.; Chan, A. P. C.; Lam, P. T. I. 2010. Preferred risk allocation in China's public-private partnership (PPP) projects, International Journal of Project Management 28(5): 482-492.

http://dx.doi.org/10.1016/j.ijproman.2009.08.007

Ke, Y.; Wang, S. Q.; Chan, A. P. C.; Cheung, E. 2011. Understanding the risks in China's PPP projects: ranking of their probability and consequence, Engineering, Construction and Architecture Management 18(5): 481-496. http://dx.doi.org/10.1108/09699981111165176

Keeney, S.; Hasson, F.; McKenna, H. P. 2001. A critical review of the Delphi technique as a research methodology for nursing, International Journal of Nursing Studies 38(2): 195-200. http://dx.doi.org/10.1016/S0020-7489(00)00044-4

Keeney, S.; Hasson, F.; Mckenna, H. 2011. The Delphi technique in nursing and health research. Chichester, West Sussex, UK: Wiley-Blackwell. 208 p.

Khasnabis, S.; Alsaidi, E.; Liu, L.; Ellis, R. D. 2002. Comparative study of two techniques of transit performance assessment: AHP and GAT, Journal of Transportation Engineering 128(6): 499-508.

http://dx.doi.org/10.1061/(ASCE)0733-947X(2002)128:6(499) 
Khazaeni, G.; Khanzadi, M.; Afshar, A. 2012. Fuzzy adaptive decision making model for selection balanced risk allocation, International Journal of Project Management 30(4): 511-522.

http://dx.doi.org/10.1016/j.ijproman.2011.10.003

Kim, J. O. 1975. Multivariate analysis of ordinal variables, The American Journal of Sociology 81(2): 261-298. http://dx.doi.org/10.1086/226074

Kumaraswamy, M. M.; Anvuur, A. M. 2008. Selecting sustainable teams for PPP projects, Building and Environment 43(6): 999-1009.

http://dx.doi.org/10.1016/j.buildenv.2007.02.001

Lee, J. W.; Kim, S. H. 2001. An integrated approach for interdependent information system project selection, International Journal of Project Management 19(2): 111-118. http://dx.doi.org/10.1016/S0263-7863(99)00053-8

Lin, K. L. 2011. Human resource allocation for remote construction projects, Journal of Management in Engineering 27(1): 13-20.

http://dx.doi.org/10.1061/(ASCE)ME.1943-5479.0000032

Lin, L. K.; Chang, C. C.; Lin, Y. C. 2011. Structure development and performance evaluation of construction knowledge management system, Journal of Civil Engineering and Management 17(2): 184-196. http://dx.doi.org/10.3846/13923730.2011.576833

Linstone, H. A.; Turoff, M. 1975. The Delphi method: techniques and applications. Addison Wesley, Reading, MA. $620 \mathrm{p}$.

Lu, W. 2010. Improved SWOT approach for conducting strategic planning in the construction industry, Journal of Construction Engineering and Management 136(12): 1317-1328. http://dx.doi.org/10.1061/(ASCE)CO.1943-7862.0000240

Lucko, G.; Rojas, E. M. 2010. Research validation: challenges and opportunities in the construction domain, Journal of Construction Engineering and Management 136(1): 127-135. http://dx.doi.org/10.1061/(ASCE)CO.1943-7862.0000025

Lyer, K. C.; Sagheer, M. 2010. Hierarchical structuring of PPP risks using interpretative structural modelling, Journal of Construction Engineering and Management 136(2): 151-159. http://dx.doi.org/10.1061/(ASCE)CO.1943-7862.0000127

Manoliadis, O. G.; Tsolas, I.; Nakou, A. 2006. Sustainable construction and drivers of change in Greece: a Delphi study, Construction Management and Economics 24(2): 113-120. http://dx.doi.org/10.1080/01446190500204804

Manoliadis, O. G.; Pantouvakis, J. P.; Christodoulou, S. E. 2009. Improving qualifications-based selection by use of the fuzzy Delphi method, Construction Management and Economics 27(4): 373-384. http://dx.doi. org/10.1080/01446190902758993

Murphy, M. K.; Black, N.; Lamping, D. L.; McKee, C. M.; Sanderson, C. F. B.; Askham, J.; Marteau, T. 1998. Consensus development methods and their use in clinical guideline development, Health Technology Assessment 2(3): 1-88.

Murray, T. J.; Pipino, L. L.; van Gigch, J. P. 1985. A pilot study of fuzzy set modification of Delphi, Human Systems Management 5(1): 76-80.

Nasirzadeh, F.; Afshar, A.; Khanzadi, M.; Howick, S. 2008. Integrating system dynamics and fuzzy logic modelling for construction risk management, Construction Management and Economics 26(11): 1197-1212. http://dx.doi.org/10.1080/01446190802459924

Norman, G. 2010. Likert scales, levels of measurement and the "laws" of statistics, Advances in Health Sciences Education 15(5): 625-632.

http://dx.doi.org/10.1007/s10459-010-9222-y

Pan, N. F. 2008. Fuzzy AHP approach for selecting the suitable bridge construction method, Automation in Construction 17(8): 958-965.

http://dx.doi.org/10.1016/j.autcon.2008.03.005
Pivo, G. 2008. Responsible property investment criteria developed using the Delphi method, Building Research and Information 36(1): 20-36. http://dx.doi.org/10.1080/09613210701574795

Rajendran, S.; Gambatese, J. A. 2009. Development and initial validation of sustainable construction safety and health rating system, Journal of Construction Engineering and Management 135(10): 1067-1075.

http://dx.doi.org/10.1061/(ASCE)0733-9364(2009)135: 10(1067)

Saaty, T. L. 1980. The analytic hierarchy process. Planning, priority setting, resource allocation. London, England: McGraw-Hill. 287 p.

Saaty, T. L. 1996. Decision making with dependence and feedback: The analytic network process. Pittsburgh: RWS Publications. 370 p.

Sarkar, D.; Dutta, G. 2010. Design and application of risk adjusted cumulative sum for strength monitoring of ready mixed concrete, Journal of Construction Engineering and Management 136(6): 623-631. http://dx.doi.org/10.1061/(ASCE)CO.1943-7862.0000170

Seo, J. W.; Choi, H. H. 2008. Risk-based safety impact assessment methodology for underground construction projects in Korea, Journal of Construction Engineering and Management 134(1): 72-81. http://dx.doi.org/10.1061/(ASCE)0733-9364(2008)134:1(72)

Shaheen, A. A.; Fayek, A. R.; AbouRizk, S. M. 2007. Fuzzy numbers in cost range estimating, Journal of Construction Engineering and Management 133(4): 325-334.

http://dx.doi.org/10.1061/(ASCE)0733-9364(2007)133:4(325)

Shapira, A.; Goldenberg, M. 2005. AHP-Based equipment selection model for construction projects, Journal of Construction Engineering and Management 130(12): 1263-1273.

http://dx.doi.org/10.1061/(ASCE)0733-9364(2005)131:12(1263)

Shapira, A.; Lyachin, B. 2009. Identification and analysis of factors affecting safety on construction sites with tower cranes, Journal of Construction Engineering and Management 135(1): 24-33.

http://dx.doi.org/10.1061/(ASCE)0733-9364(2009)135:1(24)

Shields, T. J.; Silcock, G. W.; Donegan, H. A. 1988. Towards the development of a fire safety systems evaluation for public assembly buildings, Construction Management and Economics 8(2): 147-158. http://dx.doi.org/10.1080/01446199000000013

Siegel, S.; Castellan, N. J. 1988. Nonparametric statistics for the behavioral sciences. $2^{\text {nd }}$ ed. New York: McCraw-Hill. $399 \mathrm{p}$.

Tabish, S. Z. S.; Jha, K. N. 2011. Analyses and evaluation of irregularities in public procurement in India, Construction Management and Economics 29(3): 261-274. http://dx.doi.org/10.1080/01446193.2010.549138

Thomas, A. V.; Kalidindi, S. N.; Ganesh, L. S. 2006. Modelling and assessment of critical risks in BOT road projects, Construction Management and Economics 24(4): 407-424. http://dx.doi.org/10.1080/01446190500435275

Tummala, V. M. R.; Burchett, J. F. 1999. Applying a risk management process (RMP) to manage cost risk for an EHV transmission line project, International Journal of Project Management 17(4): 223-235. http://dx.doi.org/10.1016/S0263-7863(98)00038-6

Vidal, L. A.; Marle, F.; Bocquet, J. C. 2011. Measuring project complexity using the Analytic Hierarchy Process, International Journal of Project Management 29(6): 718-727. http://dx.doi.org/10.1016/j.ijproman.2010.07.005

Weisberg, H.; Krosnick, J. A.; Bowen, B. D. 1996. An introduction to survey research, polling, and data analysis. SAGE Publications. 408 p.

Wu, C. R.; Lin, C. T.; Chen, H. C. 2007. Optimal selection of location for Taiwanese hospitals to ensure a competitive advantage by using the analytic hierarchy process and 
sensitivity analysis, Building and Environment 42(3): 1431-1444.

http://dx.doi.org/10.1016/j.buildenv.2005.12.016

Xia, B.; Chan, A. P. C. 2010. Key competences of design-build clients in China, Journal of Facilities Management 8(2): 114-129. http://dx.doi.org/10.1108/14725961011041161

Xia, B.; Chan, A. P. C. 2012a. Measuring complexity for building projects: a Delphi study, Engineering, Construction and Architecture Management 19(1): 7-24. http://dx.doi.org/10.1108/09699981211192544

Xia, B.; Chan, A. P. C. 2012b. Identification of selection criteria for operational variations of the design-build system: a Delphi study in China, Journal of Civil Engineering and Management 18(2): 173-183. http://dx.doi.org/10.3846/13923730.2012.657417

Xia, B.; Chan, A. P. C.; Yeung, J. F. Y. 2009. Identification of key competences of design-builders in the construction market of the People's Republic of China (PRC), Construction Management and Economics 27(11): 1141-1152. http://dx.doi.org/10.1080/01446190903280476

Xia, B.; Chan, A. P. C.; Yeung, J. F. Y. 2011. Developing a fuzzy multicriteria decision-making model for selecting DesignBuild operational variations, Journal of Construction Engineering and Management 137(12): 1176-1184. http://dx.doi.org/10.1061/(ASCE)CO.1943-7862.0000381

Xu, Y.; Chan, A. P. C.; Yeung, J. F. Y. 2010a. Developing a fuzzy risk allocation model for PPP projects in China, Journal of Construction Engineering and Management 136(8): 894-903. http://dx.doi.org/10.1061/(ASCE)CO.1943-7862.0000189

Xu, Y.; Yeung, J. F. Y.; Chan, A. P. C.; Chan, D. W. M.; Wang, S. Q.; Ke, Y. 2010b. Developing a risk assessment model for PPP projects in China-A fuzzy synthetic evaluation approach, Automation in Construction 19(7): 929943. http://dx.doi.org/10.1016/j.autcon.2010.06.006

Yasamis-Speroni, F.; Lee, D. E.; Arditi, D. 2012. Evaluating the quality performance of pavement contractors, Journal of Construction Engineering and Management 138(10): 1114-1124.

http://dx.doi.org/10.1061/(ASCE)CO.1943-7862.0000539
Yeung, J. F. Y.; Chan, A. P. C.; Chan, D. W. M.; Li, L. K. 2007. Development of a partnering performance index (PPI) for construction projects in Hong Kong: a Delphi study, Construction Management and Economics 25(12): 12191237. http://dx.doi.org/10.1080/01446190701598673

Yeung, J. F. Y.; Chan, A. P. C.; Chan, D. W. M. 2008. Establishing quantitative indicators for measuring the partnering performance of construction projects in Hong Kong, Construction Management and Economics 26(3): 277301. http://dx.doi.org/10.1080/01446190701793688

Yeung, J. F. Y.; Chan, A. P. C.; Chan, D. W. M. 2009a. Developing a performance index for relationship-based construction projects in Australia: Delphi study, Journal of Management in Engineering 25(2): 59-68.

http://dx.doi.org/10.1061/(ASCE)0742-597X(2009)25:2(59)

Yeung, J. F. Y.; Chan, A. P. C.; Chan, D. W. M. 2009b. A computerized model for measuring and benchmarking the partnering performance of construction projects, Automation in Construction 18(8): 1099-1113. http://dx.doi.org/10.1016/j.autcon.2009.07.003

Yeung, J. F. Y.; Chan, A. P. C.; Chan, D. W. M. 2012. Fuzzy set theory approach for measuring the performance of relationship-based construction projects in Australia, Journal of Management in Engineering 28(2): 181-192. http://dx.doi.org/10.1061/(ASCE)ME.1943-5479.0000083

Yik, F. W.; Lai, J. H.; Lee, W. L.; Chan, K. T.; Chau, C. K. 2012. A Delphi study on building services engineers' core competence and statutory role in Hong Kong, Journal of Facilities Management 10(1): 26-44. http://dx.doi.org/10.1108/14725961211200388

Yu, J. H.; Kwon, H. R. 2011. Critical success factors for urban regeneration projects in Korea, International Journal of Project Management 29(7): 889-899.

http://dx.doi.org/10.1016/j.ijproman.2010.09.001

Zadeh, L. A. 1965. Fuzzy sets, Information and Control 8(3): 338-853. http://dx.doi.org/10.1016/S0019-9958(65)90241-X

Zhao, X.; Hwang, B. G.; Yu, G. S. 2013. Identifying the critical risks in underground rail international construction joint ventures: case study of Singapore, International Journal of Project Management 31(4): 554-566.

http://dx.doi.org/10.1016/j.ijproman.2012.10.014

Effah Ernest AMEYAW. He is a Research Associate of Department of Building and Real Estate, The Hong Kong Polytechnic University. His current research interest is risk management of public-private partnership projects in Ghana.

Yi HU. He is an Assistant Professor of Department of Construction Management and Real Estate, School of Economics and Management, Tongji University. His current research interest centers on megaproject organization and management in China and other locations.

Ming SHAN. He is a Joint PhD Candidate of The Hong Kong Polytechnic University, and Tongji University, who already received a PhD degree in Building and Real Estate from The Hong Kong Polytechnic University. His current research interest is professional ethics in the construction industry.

Albert P. C. CHAN. He is Chair Professor and Head of Department of Building and Real Estate, The Hong Kong Polytechnic University. His research interests are megaproject management, public-private partnership project management, construction safety, construction professional ethics, and innovation in construction.

Yun LE. He is Professor and Head of Department of Construction Management and Real Estate, and Associate Director of Research Institute of Complex Engineering \& Management, School of Management and Economics, Tongji University. His research interests focus on ethical behaviors in the public construction sector and megaproject management in China and worldwide. 